\title{
Experimental Research on Strength of Concrete Prepared by using Coarse Aggregate from Concrete Debris
}

\author{
Vishnu.A, Syed Aadil Moosvi, Abiraagav, Ponmalar. V
}

\begin{abstract}
Cement is the blend of cement, fine aggregate, coarse aggregate with addition of water. In this coarse aggregate plays the main role. But the resources of coarse aggregate get reduces day by day. So we have to found out the alternate way. The complete quantum of waste from development industry is evaluated to be 12 to 14.7 million tons for each annum out of which 7 to 8 million tons are concrete and block squander in India. These days, practically all obliterated cement has been for the most part dumped to landfills. As concrete is a basic, masscreated material in the development business, endeavours have been made to reuse and to monitor it. Solid reusing have as of late turned out to be significant parts of the development business. Solid reusing can be cultivated by reusing solid items, and after that prepared into optional crude materials as filling materials, street bases and sub bases or total for the creation of new concrete. The utilization of reused totals from development and destruction squanders is indicating planned application in development as option in contrast to essential totals. It preserves regular assets and lessens the space required for the landfill transfer. Recycled aggregates are comprised of crushed and graded materials that have been utilized in the development. The point of our research is to decide the characteristic quality of reused totals for application in basic individuals, which can give a superior comprehension on the properties of reused totals as an alternate material to coarse aggregate in structural elements. By using this material the area for damping the concrete debris in the landfills and the emission of $\mathrm{CO} 2$ during the mining of the aggregates can be minimized. Reduces the impact on landfills by which the land area can be used for other useful purposes like construction of transmission towers, mobile towers etc., Makes the cost investment funds in the transportation of total, and waste items and in waste transfer. There are both environmental and economic benefits of using recycled concrete aggregate.
\end{abstract}

\section{INTRODUCTION}

Concrete is the blend of cement, fine and coarse aggregate with expansion of water. In this coarse aggregate plays the main role as occupying nearly up to $75 \%$ in it. But the resources of coarse aggregate get reducing day by day. So we have to find out alternate ways.

So as to lessen the utilization of common aggregate, reused aggregate can be utilized as the substitution materials. Reused totals are included squashed, reviewed inorganic particles prepared from the materials that have been utilized in the destruction flotsam and jetsam. As per

Revised Manuscript Received on 14 August, 2019.

Vishnu.A, Assistant professor, Department of Civil Engineering, Kumaraguru College of Technology, Coimbatore, Tamilnadu, India.(Email: vishnu.a.ce@kct.ac.in)

Syed AadilMoosvi, UG student Department of Civil Engineering, Kumaraguru College of Technology, Coimbatore, Tamilnadu, India.(Email: syedaadil.17ce@kct.ac.in)

Abiraagav, UG student Department of Civil Engineering, Kumaraguru College of Technology, Coimbatore, Tamilnadu, India. Anna University, Chennai, Tamilnadu, India.
Ponmalar.V, Associate Professor, Department Of Structural Division,

CSIRO, Construction and destruction squander (C\&D waste)makes up to $40 \%$ of the complete waste every year (gauge around 14 million tons) going to landfill. C\&D contains mainly crushed concrete and other materials such as metals, bricks, plastics, etc. The waste can be processed to produce high quality Recycled Concrete Aggregate (RCA) through a proper processing plant.

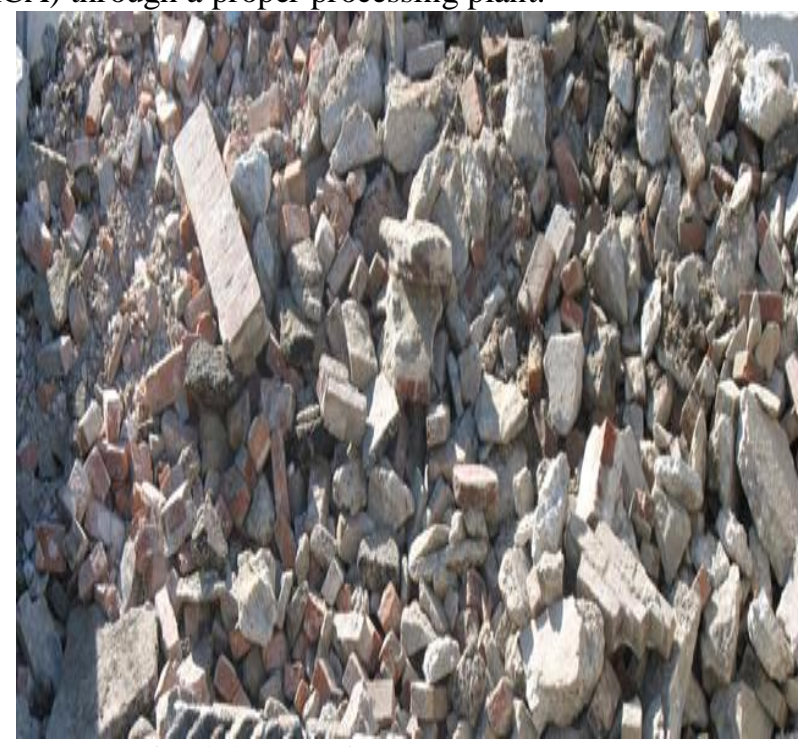

Fig. 1.1 Demolished concrete waste

The primary purposes behind increment of volume of destruction concrete/stone work waste are as per the following:-

I. Numerous old structures, solid asphalts, extensions and different structures have beaten their age and cutoff of utilization because of basic decay past fixes and should be annihilated;

ii. The structures, even sufficient to utilize are under destruction since they are not serving the requirements in present situation;

iii. New development for better financial development;

iv. Structures are diverted into garbage coming about because of cataclysmic events like quake, violent wind and floods and so forth.

Reusing is the procedure that takes squander things and transforms them into crude materials that can be made into new items. The reusing procedure starts with the accumulation of recyclable things, which are sent to a plant where they can be arranged and arranged for reuse.
Blue Eyes Intelligence Engineering $\&$ Sciences Publication 
Reused solid total (RCA). RCA is granular material made by evacuating, pounding, and preparing for reuse with an establishing medium to create crisp clearing concrete. The total held on the $4.75 \mathrm{~mm}$ (No. 4) strainer is called coarse total; material passing the $4.75 \mathrm{~mm}$ (No. 4) sifter is called fine total. Reused solid total is precise with harsh surfaces, has higher water ingestion limit, lower explicit gravity, higher Los Angeles

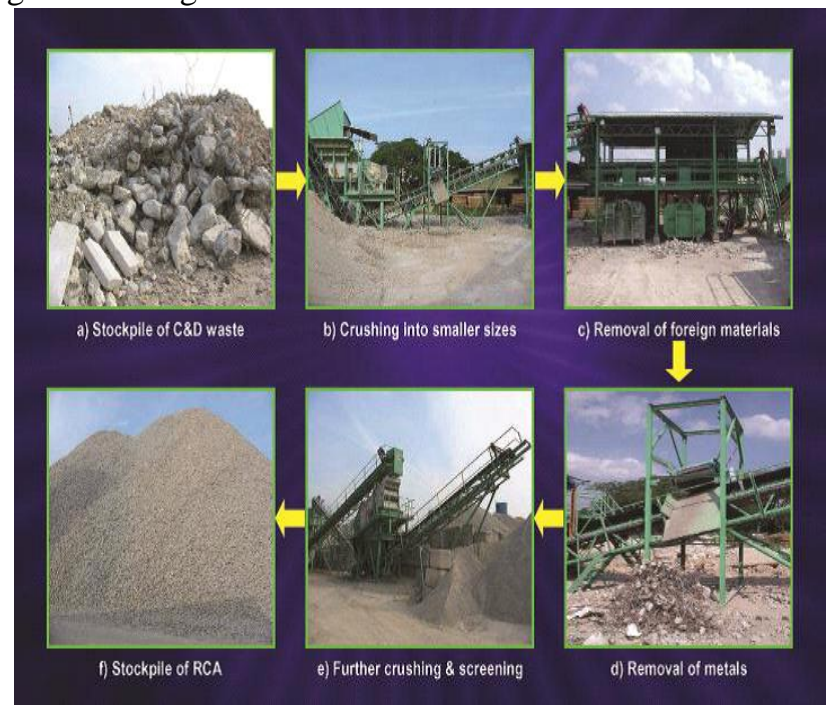

Fig 1.3 Process of Recycling concrete

Process of Recycling the Demolished Concrete waste the demolished construction waste was collected from the site. The collected waste was sent through the suitable crusher to crush into required sizes. Then the other materials like metals and wooden particulars were removed. The finer particulars were removed from crushed materials by sieving and screening processes. Finally the Recycled concrete aggregates (RCA) was collected as per its sizes and be used in constructions.

So as to create amazing concrete for the new application, RCA total should:

1. Be free of unsafe parts, for example, soil, black-top, and steel. Over $90 \%$ of the material ought to be bond glue and total. Black-top substance ought to be under 1 percent;

2. Be free of destructive parts, for example, chlorides and receptive materials except if relief measures are taken to counteract repeat of MRD in the new concrete; and

3. Have water assimilation of under 10 percent.

4. Thickness of RCA will ordinarily be somewhat not as much as that of the first material utilized. This will affect proportioning the new concrete. Expect RCA to have higher water retention than that of the first total.

\subsection{Literature Review}

2.2 Reused Concrete as Aggregate for Structural Concrete Production-MirjanaMalesev, VlastimirRadonjanin and SnezanaMarinkovic ( 30 April 2010),concluded that Reused total cement (RAC) had a palatable execution, which did not vary altogether from the presentation of control concrete in their exploratory research.

2.3 Squashed Returned Concrete as Aggregates for New concrete-KarthikObla, Haejin Kim and Colin Lobo ( September 2007) stated that Utilization of CCA altogether benefits maintainable advancement by diminishing the need of land filling returned cement and saves the utilization of progressively rare great quality virgin total.

2.4 Use of Recycled Aggregate in Concrete S.K.Singh.Scientist.This Recycled aggregate conserves normal assets and decrease the space required for the landfill transfer. The compressive, elastic and flexural quality of reused total are overall $85 \%$ to $95 \%$ of the regular total cement. The strength parameters explored for reused cement are observed to be in great concurrence with BIS determinations.

2.5 RILEM Technical Committee 198-URM-utilization of $20 \%$ of squashed solid totals in auxiliary cement is currently broadened practice in numerous European Countries. Y.Dosho - Recycled coarse total solid utilizing the total supplanting technique can gain adequate quality as auxiliary cement through material plan by utilizing material fitting in with all related quality principles.

2.6 Ecological Enhancement Through Use of Recycled Aggregate Concrete in a Two-Stage Mixing ApproachTam.V,(April 2006 ) study shows that the reused total has been utilized in different development applications essentially as sub-level, street work and unbound materials has brought.

2.7 Extending the use of Usage of Recycled Concrete Aggregate for Structural Concrete - PilarAlaejosGutiérrez , Marta Sánchez de Juan ( 2001). Reused total does not satisfy determination of Spanish Standard for Structural Concrete (EHE), so it ought to be utilized mixed with common totals of improved properties.

2.8 Reused Aggregate as an economical structure development material in Housing Authority development works-The Hong Kong SAR Government has proclaimed various measures to more readily deal with the $C \& D$ squanders with the end goal of keeping up the natural manageability and advancing the utilization of RA and RAC is one of these measures. The expense of setting up and working offices to deliver RA as a way to arranging C\&D squanders contrasts positively and the expense for giving and keeping up the customary landfill offices for arranging the squanders.

2.9 Appraisal of strength of reused total cement created by two-arrange blending approach-Tam,Vivian; Tam, C.(May 2007), Study shows The Two-Stage Mixing Approach (TSMA) for improving the quality of RAC, prompting the likelihood in applying RAC for higher-grade applications. The Normal Mixing Approach (NMA) and the TSMA analysis results feature that: (I) the higher the substitutions of RA, the flimsier the exhibition of RAC; and (ii) the twisting and penetrability of RAC can be improved when embracing TSMA.

2.10 Strength and Durability of Recycled Aggregate Concrete-Mandal, Saroj; Gupta, Arundeb. Has studied that the $10 \%$ expansion of fly fiery debris likewise improves the toughness of RAC and give a solid help to the practicality of utilizing reused total rather than regular total. 


\section{MATERIAL AND METHODS}

\subsubsection{Materials}

We are choose the project in reused coarse aggregate in cement for that we collect the debris concrete in "Coimbatore

\section{METHODS}

Here we refer the 4 types of mix design, based on various amount of fine and coarse aggregate.

NOMINAL MIX: Normally used fine aggregate and coarse aggregate for M30 evaluation concrete according to IS 10262-1982.

RECYCLED MIX: Same as nominal mix but the weight of fine \& coarse aggregate valves will be changed.

RECYCLED MIX: Here normally used coarse and the fine aggregate is recycled at various amount.

RECYCLED MIX: Same as recycled mix these coarse aggregate will be used at various amount.

\section{MIX DESIGN}

Blend configuration is the way toward choosing appropriate elements of cement and deciding their relative extents with the object of delivering cement of certain base quality and strength as monetarily conceivable.

\section{Blend DESIGN FOR M30 GRADE CONCRETE (NOMINAL MIX)}

Blend plan for M30 evaluation concrete by Indian Standard suggested technique for solid blend structure according to configuration code May be: 10262-1982 (100\% NOMINAL AGGREGATE $+0 \%$ RECYCLED CONCRETE)

\section{a. Design stipulations}

i. Trademark compressive quality required in field at 28 days $30 \mathrm{~N} / \mathrm{mm} 2$

ii. Greatest size of aggregate is $20 \mathrm{~mm}$

iii. Level of value control Good

iv. Type of exposure Mild

b) Test information for materials

i. Cement utilized OPC

ii. Specific gravity of cement 3.15

iii. Specific gravity of fine aggregate 2.60

iv. Specific gravity of coarse aggregate 2.88

c) Target mean quality of cement

For a resilience factor of 1.65 and utilizing Table 1, the objective mean quality for the predefined trademark $3 \mathrm{D}$ square quality is given by

$\mathrm{fck}=\mathrm{fck}+\mathrm{ts}$

$=30+(4 \mathrm{x} 1.65)=36.6 \mathrm{~N} / \mathrm{mm} 2$

d) Selection of water bond proportion

From IS: 10262-1982, for the free water - concrete proportion for the objective mean quality of $36.6 \mathrm{~N} / \mathrm{mm} 2$ is 0.4

e) Estimation of entrapped air
From Table 3 of IS10262-1982, for the predetermined most extreme size of total of $20 \mathrm{~mm}$, the measure of captured air in the wet cement is 2 percent.

\section{f) Selection of Water and Sand content}

For $10 \mathrm{~mm}$ most extreme size total, Sand fitting in with reviewing zone III

Water content per cubic meter of cement $=186 \mathrm{~kg}$

Sand content as rate by supreme volume $=35 \%$

$=35-3.5=31.5 \%$

\section{g) Determination of bond content}

Water bond ratio $=0.4$

Water $=186$ lit

Cement $=(186 / 0.4)=465 \mathrm{~kg} / \mathrm{m} 3$

But as per IS code the maximum cement content should be $450 \mathrm{~kg} / \mathrm{m} 3$.

Therefore, the cement content $=450 \mathrm{~kg} / \mathrm{m} 3$

\section{h) Assurance of fine and coarse total Contents}

For the predefined most extreme size of total, the measure of captured air is in the wet cement is $2 \%$. Considering,

$\mathrm{V}=[\mathrm{W}+(\mathrm{C} / \mathrm{Sc})+(1 / \mathrm{P})(\mathrm{fa} / \mathrm{Sfa})](1 / 1000)$

Table 4.1 Design mix of concrete with nominal coarse aggregate

\begin{tabular}{|c|c|c|c|}
\hline Water & Cement & Fine aggregate & Nominal coarse aggregate \\
\hline 186 & $450 \mathrm{~kg}$ & $641.146 \mathrm{~kg}$ & $1501.038 \mathrm{~kg}$ \\
\hline 0.41 & 1 & 1.425 & 3.33 \\
\hline
\end{tabular}

Table 4.2 Design mix of concrete with recycled coarse aggregate

\begin{tabular}{|c|c|c|c|}
\hline Water & Cement & Fine aggregate & Nominal coarse aggregate \\
\hline 250 & $450 \mathrm{~kg}$ & $547.396 \mathrm{~kg}$ & $1249.54 \mathrm{~kg}$ \\
\hline 0.56 & 1 & 1.21 & 2.77 \\
\hline
\end{tabular}

\section{DETAILS OF TESTING}

\section{Casting Of Test Specimens}

In general, we taken five types of testing in these specimen that is following below: Batching, Mixing, Curing, Compressive strength, Fineness (Sieve analysis)

The examples were casted and permitted to remedy for 28 days and were tried. The subtleties of testing are pursues: 


\section{EXPERIMENTAL RESEARCH ON STRENGTH OF CONCRETE PREPARED BY USING COARSE AGGREGATE FROM CONCRETE DEBRIS}

\section{COLLECTION}

Table 5.1 Sieve Analysis Of Recycled Coarse Aggregate

\begin{tabular}{|c|c|c|c|c|c|}
\hline S1.No. & I.S. sieve & $\begin{array}{c}\text { Wt of } \\
\text { retained } \\
(\mathbf{k g})\end{array}$ & $\begin{array}{c}\text { Cumulative } \\
\% \text { Wt } \\
\text { retained(kg) }\end{array}$ & $\begin{array}{c}\text { Cumulative } \\
\% \text { of } \\
\text { retained }\end{array}$ & $\begin{array}{c}\text { Cumulative } \\
\% \text { passing }\end{array}$ \\
\hline 1. & $80 \mathrm{MM}$ & - & - & - & - \\
\hline 2. & $40 \mathrm{MM}$ & - & - & - & - \\
\hline 3. & $20 \mathrm{MM}$ & - & - & - & - \\
\hline 4. & $10 \mathrm{MM}$ & - & - & - & 100 \\
\hline 5. & $4.75 \mathrm{MM}$ & 9.8 & 9.5 & 1 & 99 \\
\hline 6. & $2.36 \mathrm{MM}$ & 45 & 50 & 5 & 95 \\
\hline 7. & $1.18 \mathrm{MM}$ & 70 & 120 & 12 & 88 \\
\hline 8. & $600 \mu$ & 170 & 290 & 29 & 71 \\
\hline 9. & $300 \mu$ & 570 & 860 & 86 & 14 \\
\hline 10. & $150 \mu$ & 120 & 980 & 98 & 2 \\
\hline 11. & $<150 \mu$ & 20 & 1000 & 100 & 0 \\
\hline
\end{tabular}

Based on the sieve results we came to conclude that the sample which retain in sieve 4.75 is about $99 \%$ and thus there is availability 4.75 size aggregate.

Table 5.2 Sifter Analysis Of Recycled Fine Aggregate

\begin{tabular}{|c|c|c|c|}
\hline S1.No. & Sieve Size & $\begin{array}{c}\text { Fine } \\
\text { Aggregate(Grams) }\end{array}$ & $\begin{array}{c}\text { Fine } \\
\text { Aggregate(\% } \\
\text { Finer) }\end{array}$ \\
\hline 1. & $4.75 \mathrm{~mm}$ & 0 & 99.6 \\
\hline 2. & $2.36 \mathrm{~mm}$ & 2 & 99 \\
\hline 3. & $1.18 \mathrm{~mm}$ & 3 & 77 \\
\hline 4. & $600 \mu$ & 110 & 22.8 \\
\hline 5. & $300 \mu$ & 271 & 5.8 \\
\hline 6. & $150 \mu$ & 85 & 0.4 \\
\hline 7. & $75 \mu$ & 27 & 0 \\
\hline 8. & Pan & 2 & \\
\hline
\end{tabular}

Based on the sieve results we came to conclude that the sample which retain in sieve 2.36 is about $99 \%$ and thus there is availability 2.36 size aggregate.

Table 5.3 sifter analysis of coarse aggregate.

\begin{tabular}{|c|c|c|c|c|c|}
\hline S1.No. & I.S. sieve & $\begin{array}{c}\text { Wt of } \\
\text { retained } \\
(\mathbf{k g})\end{array}$ & $\begin{array}{c}\text { Cumulative } \\
\% \mathbf{W t} \\
\text { retained(kg) }\end{array}$ & $\begin{array}{c}\text { Cumulative } \\
\% \text { of } \\
\text { retained }\end{array}$ & $\begin{array}{c}\text { Cumulative } \\
\% \text { passing }\end{array}$ \\
\hline 1. & $80 \mathrm{~mm}$ & 0 & 0 & 0 & 100 \\
\hline 2. & $40 \mathrm{~mm}$ & 0 & 0 & 0 & 100 \\
\hline 3. & $20 \mathrm{~mm}$ & 2.530 & 2.530 & 2.530 & 74.7 \\
\hline 4. & $10 \mathrm{~mm}$ & 7.390 & 9.920 & 73.9 & 26.7 \\
\hline 5. & $4.75 \mathrm{~mm}$ & 0.060 & 10.52 & 0.6 & 99.4 \\
\hline 6. & $2.36 \mathrm{~mm}$ & 0 & 0 & 100 & 0 \\
\hline 7. & $1.18 \mathrm{~mm}$ & 0 & 0 & 100 & 0 \\
\hline 8. & $600 \mu$ & 0 & 0 & 100 & 0 \\
\hline 9. & $300 \mu$ & 0 & 0 & 100 & 0 \\
\hline 10. & $150 \mu$ & 0 & 0 & 100 & 0 \\
\hline 11. & $<150 \mu$ & 0 & 0 & 100 & 0 \\
\hline
\end{tabular}

Based on the sifter results we came to conclude that the sample which retain in sieve 4.75 is about $99 \%$ and thus there is availability 4.75 size aggregate.

Table 5.4 Sieve Analysis Of Fine Aggregate

\begin{tabular}{|c|c|c|c|c|c|c|}
\hline Sl.No. & L.S. sieve & $\begin{array}{c}\text { Size of } \\
\text { opening } \\
\text { (mm) }\end{array}$ & $\begin{array}{c}\text { Wt. } \\
\text { retained } \\
\text { (gms) }\end{array}$ & $\begin{array}{c}\% \text { Wt } \\
\text { retained }\end{array}$ & $\begin{array}{c}\text { Cumulative } \\
\% \text { Wt } \\
\text { retained }\end{array}$ & \% finer \\
\hline 1. & $4.75 \mathrm{~mm}$ & 4.75 & 4 & 0.6 & 0.4 & 99.6 \\
\hline 2. & $2.36 \mathrm{~mm}$ & 2.36 & 27 & 3 & 3.7 & 96.9 \\
\hline 3. & $1.18 \mathrm{~mm}$ & 1.18 & 103 & 15.6 & 13.4 & 86.6 \\
\hline 4. & $600 \mu$ & 0.60 & 253 & 27.4 & 28.7 & 61.3 \\
\hline 5. & $425 \mu$ & 0.425 & 301 & 19.6 & 38.8 & 31.2 \\
\hline 6. & $300 \mu$ & 0.30 & 124 & 18 & 31.2 & 18.8 \\
\hline 7. & $150 \mu$ & 0.150 & 5 & 14.2 & 41.7 & 18.3 \\
\hline 8. & $75 \mu$ & 0.075 & 173 & 1.4 & 49.0 & 1.0 \\
\hline 9. & Pan & 0 & 4 & 0.2 & 49.4 & 0.9 \\
\hline
\end{tabular}

Based on the sieve results we came to conclude that the sample which retain in sieve 2.36 is about $99 \%$ and thus there is availability 2.36 size aggregate.

\section{TEST ON COMPRESSIVE STRENGTH\& RESULTS}

Table 6.1 Compressive load

\begin{tabular}{|c|c|c|c|c|}
\hline PROPORTIONS & $\begin{array}{l}\text { DAYS OF } \\
\text { SPECIMIEN } \\
\text { TEST }\end{array}$ & $\begin{array}{c}\text { LOAD } \\
(\mathrm{kN})\end{array}$ & $\begin{array}{c}\text { COMIPRESSIVE } \\
\text { STRENGTH IN } \\
\mathrm{N} / \mathrm{mm}^{2}\end{array}$ & $\begin{array}{c}\text { AVERAGE } \\
\text { COMIPRESSIVE } \\
\text { STRENGTH N } \\
\mathrm{N} / \mathrm{mm}^{2}\end{array}$ \\
\hline \multirow{3}{*}{ NOMINAL MIX } & 3 & 650 & 28.88 & \multirow{3}{*}{33.55} \\
\hline & 14 & 712 & 31.64 & \\
\hline & 28 & 903 & 40.13 & \\
\hline \multirow{3}{*}{$\begin{array}{l}\text { REPLACEMENT } \\
\text { OF COARSE } \\
\text { AGGREGATE }\end{array}$} & 3 & 550 & 24.4 & \multirow{3}{*}{32.93} \\
\hline & 14 & 770 & 34.2 & \\
\hline & 28 & 905 & 40.2 & \\
\hline \multirow{3}{*}{$\begin{array}{c}\text { REPLACEMENT } \\
\text { OF FINE } \\
\text { AGGREGATE }\end{array}$} & 3 & 450 & 20.4 & \multirow{3}{*}{27.63} \\
\hline & 14 & 670 & 29.7 & \\
\hline & 28 & 740 & 32.8 & \\
\hline \multirow{3}{*}{$\begin{array}{c}\text { REPLACEMENT } \\
\text { OF FINE } \\
\text { AGGREGATE }\end{array}$} & 3 & 595 & 26.36 & \multirow{3}{*}{31.90} \\
\hline & 14 & 735 & 32.67 & \\
\hline & 28 & 825 & 36.68 & \\
\hline
\end{tabular}

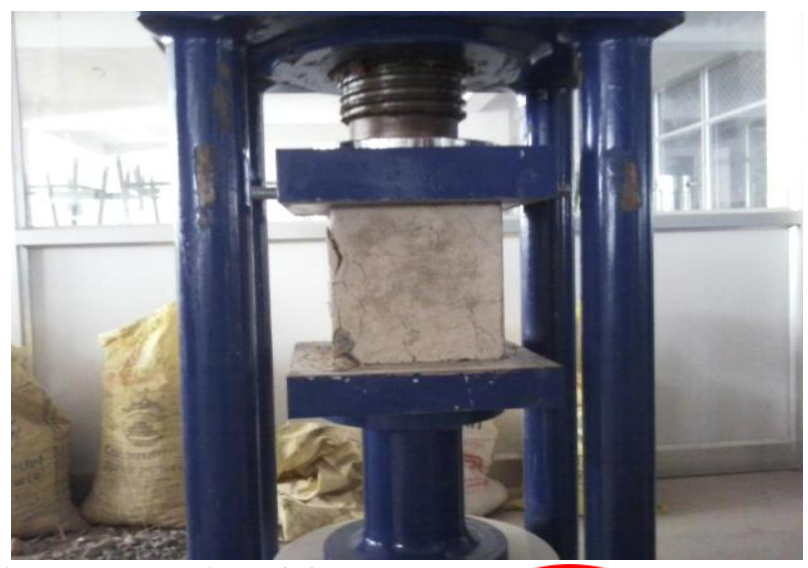

Figure 6.1 Testing of Cube

Published By: 


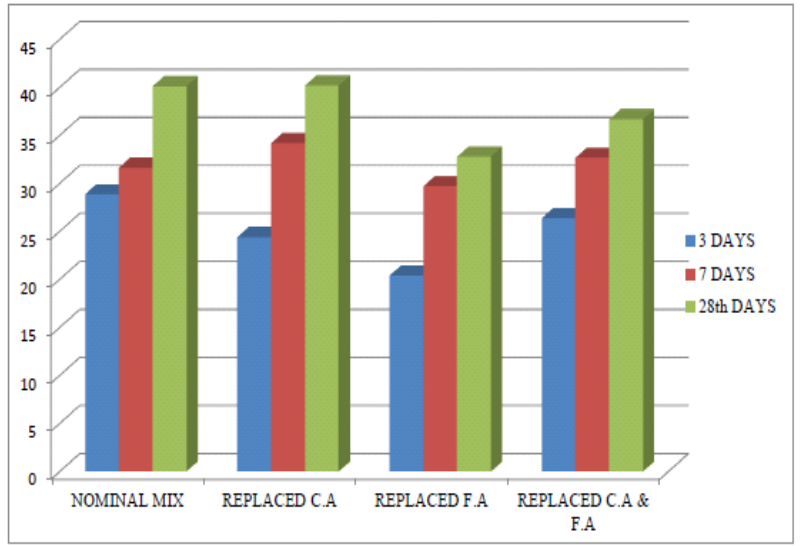

Figure 6.2 Result Analysis

Based on test results the compression strength was maximum at nominal of $40.13 \mathrm{~N} / \mathrm{mm} 2$. At replacement of coarse aggregate the compression strength is $40.2 \mathrm{~N} / \mathrm{mm} 2$. And while replacing the fine aggregate by recycled fine aggregate the strength gets reduced to $32.8 \mathrm{~N} / \mathrm{mm} 2$ at replacement of fine aggregate. By replacement of recycled coarse and fine aggregate to $36.68 \mathrm{~N} / \mathrm{mm} 2$.

\section{CONCLUSIONS}

The compressive strength of the cube for natural aggregate is achieved as $33.55 \mathrm{~N} / \mathrm{mm} 2$. While replacing the natural aggregate by recycled aggregate the compressive strength are $32.93 \mathrm{~N} / \mathrm{mm} 2,27.63 \mathrm{~N} / \mathrm{mm} 2,31.90 \mathrm{~N} / \mathrm{mm} 2$ replacement level.

$\square \square$ The compressive quality is limit of $32.90 \mathrm{~N} / \mathrm{mm} 2$ at substitution of ostensible coarse total by reused coarse total.

$\square \square$ The compressive quality of the block for ostensible total is less contrasted with supplanting the ostensible total by reused total.

$\square \square$ Use of reused solid total moderates regular total, diminishes the effect on landfill and makes cost reserve funds in the transportation of total, squander items and in waste transfer. It diminishes the effect on waning landfill space, decreases transfer costs, and may lessen by and large undertakings costs.

$\square \square$ There are both environmental and economic benefits of using recycled concrete aggregate.

\section{REFERENCES}

1. Arlindogoncalves, Influence of Recycled concrete aggregate in concrete durability, National lab of civil engineering, Portugal.

2. Bodin and Zaharieva(2002), "Influence of industrially produced recycled aggregate on flow properties of concrete", Materials and structures, Vol 35, No-8, Pages 504-509

3. Gambhir.M.L. (2009), "Concrete technology", 4th edition Tata M C Graw Hill Education Private Limited, New Delhi.

4. Karthik obla, etc (2007) "Crushed Returned concrete as aggregates for new concrete" RMC Research and education foundation, September 2007.

5. Keith W.Anderson, Jeff S.Uhlmeger, and Mark Russell "Use of Recycled Concrete Aggregate in PCCP: literature Search. June 2009

6. Kumutha.R and Vijai.K (2010), "Strength of concrete incorporating aggregates recycled from demolition waste" ARPN Journal of Engineering and Applied Sciences, VOL. 5, NO. 5,64-71

7. Nelson, Shing Chai NGO (2004) "High-Strength Structural Concrete with recycled aggregate.

8. Santhakumar.A.R (2007), "Concrete technology", Oxford University Press

9. Shetty.M.S. (2009), "Concrete technology", S.Chand publishers

10. Struart G. Park (1999), "Recycled concrete construction Rubble as aggregate for new concrete", The Resource centre for building Excellence, Study report No.86. 